Tersedia online di: http://ejournal-balitbang.kkp.go.id/index.php/bawal
e-mail:bawal.puslitbangkan@ @mail.com
BAWAL wIDYA RISET PERIKANAN TANGKAP
Volume 10 Nomor 1 April 2018
p-ISSN: 1907-8226
e-ISSN: 2502-6410
BAWAL
Nomor Akreditasi: $620 / A U 2 / P 2 M I-L I P I / 03 / 2015$
BAWAL

\title{
BIOLOGI REPRODUKSI IKAN TONGKOLABU-ABU (Thunnus tonggol) DI PERAIRAN LAUT CINA SELATAN
}

\section{REPRODUCTIVE BIOLOGY OF LONGTAIL TUNA (Thunnus tonggol) IN THE SOUTH CHINA SEA}

\author{
Thomas Hidayat*1, dan Tegoeh Noegroho ${ }^{1}$ \\ ${ }^{1}$ Balai Riset Perikanan Laut, Cibinong, Bogor, Jl. Raya Bogor KM. 47 Cibinong, Bogor- Jawa Barat, Indonesia \\ Teregistrasi I tanggal: 07 Desember 2016; Diterima setelah perbaikan tanggal: 09 Januari 2018; \\ Disetujui terbit tanggal: 25 Januari 2018
}

\begin{abstract}
ABSTRAK
Ikan tongkol abu-abu (Thunnus tonggol) tertangkap di Laut Cina Selatan dan bernilai ekonomis penting. Trend produksi berfluktuatif, 2009-2011 meningkat, menurun pada 2013 dan 2015 meningkat kembali. Seiring dengan meningkatnya permintaan, pemanfaatan tongkol abu-abu harus dikelola agar ketersediaannya tetap berkesinambungan. Tujuan penelitian adalah mengkaji biologi reproduksi ikan tongkol abu-abu sebagai bahan kebijakan pengelolaan yang lestari. Kajian yang dilakukan meliputi struktur ukuran, hubungan panjang dan berat, nisbah kelamin, tingkat kematangan gonad (TKG), indeks kematangan gonad (IKG), rata-rata ukuran pertama kali tertangkap dan matang gonad serta kebiasaan makanan. Pengumpulan sampel dilakukan oleh enumerator di PPN Pemangkat, Kalimantan Barat pada Januari sampai November 2014. Data yang dikumpulkan meliputi panjang, berat, jenis kelamin, tingkat kematangan gonad, dan isi lambung. Hasil penelitian menunjukkan sebaran panjang ikan tongkol abu-abu pada kisaran 29-80 cmFL dan modus 47-49 cmFL, pertumbuhan bersifat isometrik, nisbah kelamin jantan dan betina menunjukkan kondisi seimbang, ukuran rata-rata pertama kali tertangkap ( $L c$ ) pada panjang 47,8 cmFL, ukuran pertama kali matang gonad $(\mathrm{Lm})$ 41,1 cmFL. Dari data TKG dan IKG, prediksi musim pemijahan berlangsung pada Mei dan Agustus. Hasil pengamatan isi lambung menunjukkan bahwa ikan tongkol abu-abu tergolong ikan karnivora. Dari hasil penelitian rekomendasi untuk kebijakan pengelolaan adalah penetapan penutupan musim dan daerah penangkapan pada bulan Mei dan Agustus pada wilayah perairan yang diduga sebagai daerah pemijahan, penetapan kuota ukuran tangkapan lebih besar dari Lm $41,1 \mathrm{cmFL}$ dan alternatif wisata pancing dengan ukuran mata pancing yang hanya menangkap ukuran yang sudah matang gonad .
\end{abstract}

Kata Kunci: Biologi reproduksi; tongkol abu-abu; musim pemijahan; Laut Cina Selatan

\section{ABSTRACT}

Longtail tuna (Thunnus tonggol) were caught in the South China Sea has important economic value. The catch trend fluctuates, increase in 2009 - 2011, decrease in 2013 and increase in 2015. High demand of this resource asked a proper management to ensure sustainability. The objective of the research was to investigate the reproductive biology of longtail tuna as an recommendation of fisheries management. Analysis was conducted to examine the size structure, the length and weight relationship, sex ratio, maturity stage, gonad somatic index (GSI), Length at first capture and Length at first maturity and food habits. Sample collection was conducted monthly by enumerators in the Pemangkat Fishing Port, West Kalimantan in January to November 2014. Data containing length, weight, sex, maturity stage, and stomach contents. The results showed that the length of longtail tuna in range of $29-80 \mathrm{cmFL}$ and the mode of $47-49 \mathrm{cmFL}$, the growth is isometric, the sex ratio male and female showed a balanced condition, the average Length at first capture (Lc) at $47.8 \mathrm{cmFL}$, Length at first maturity (Lm) $41.1 \mathrm{cmFL}$. Based on maturity stage and GSI data, it predict that the spawning season takes place in May and August. Observations of the stomach contents showed longtail tuna is carnivorous fish. It suggest the close seasons and close areas in May and August on the location suspected as spawning areas, determination of the legal size is bigger than $41.1 \mathrm{cmFL}$ and encourage the recreational fishing as an alternative with specific size of the hook that caught the mature size fish.

\section{Keywords: Biology; longtail tuna; spawning season; South China Sea}




\section{PENDAHULUAN}

Ikan tongkol abu-abu (Thunnus tonggol) adalah ikan pelagis yang mempunyai nilai ekonomis dalam perikanan Indonesia. Penyebaran spesies ini tergolong unik dibandingkan spesies lain yang termasuk genus Thunnus yang umumnya ditemukan di laut dalam. Tongkol abuabu hanya ditemukan di perairan dangkal yang dekat daratan atau kepulauan (Yesaki, 1991). Menurut Cheunpan (1984) ikan tongkol abu-abu ini termasuk neritik tuna yang tertangkap di perairan sekitar 15-30 mil laut dari darat dengan kedalaman 20-45m. Spesies ini terdapat di perairan tropis dan subtropis di wilayah Indo Pasifik antara $47^{\circ} \mathrm{LU}$ sampai $33^{\circ}$ LS (Froese \& Pauly, 2009). Menurut Collete \& Nauen (1983) penyebaran ikan ini terdapat di perairan Indo Pasifik mulai selatan Jepang, Filipina, Papua Nugini sampai Australia dan ke arah barat dari perairan India, Semenanjung Arab, Laut Merah sampai Pantai Somalia.

Perairan Laut Cina Selatan (LCS) merupakan daerah penangkapan ikan tongkol yang potensial pada kedalaman rata-rata $70 \mathrm{~m}$. Hasil tangkapan di perairan LCS didaratkan di beberapa wilayah sekitarnya, seperti Bangka Belitung, Tanjung Pinang dan Pemangkat. PPN Pemangkat merupakan salah satu tempat pendaratan utama dari kapalkapal ikan yang beroperasi di Laut Cina Selatan, Laut Natuna dan sekitarnya. Produksi pelagis besar yang didaratkan di PPN pemangkat mencapai $48 \%$ dari total produksi seluruh Laut Cina Selatan, Laut Natuna dan sekitarnya. Produksi tuna neritik (tongkol komo, tongkol abu-abu dan tenggiri) sebanyak $84 \%$ diperoleh dari kapal jaring insang hanyut (drift gill net), dan 26\% diperoleh dari kapal pukat cincin (purse seine). Menurut Wujdi \& Suwarso (2014), komposisi hasil tangkapan jaring insang hanyut Pemangkat dengan rata-rata operasi 10 hari adalah tongkol komo 49,7\%, tongkol abu-abu 33,4\% dan tenggiri $15,9 \%$.

Produksi tongkol abu-abu di PPN Pemangkat menunjukkan tren fluktuatif dalam beberapa tahun terakhir, produksi tahun 2009 sebesar 4295 ton meningkat sampai 6125 ton di tahun 2011, produksi menurun sampai 3241 ton di tahun 2013 kemudian kembali naik di tahun 2015 sebesar 3617 ton. Hasil tangkapan per upaya (CPUE) jarring insang hanyut masih meningkat dari tahun 4,1 ton/trip pada 2009 sampai 5,7 ton/trip pada tahun 2011, CPUE menurun di tahun 2012 sebesar 3,3 ton/trip selanjutnya tren CPUE cenderung mendatar sampai tahun 2015 sebesar 3,5 ton/trip.

Secara umum tampak tingkat eksploitasi intensif dengan tren CPUE yang sudah mendatar, sementara permintaan pasar terus meningkat, oleh karena itu perlu upaya pengelolaan agar penangkapan bisa berkelanjutan. Penelitian biologi ikan tongkol abu-abu penting dilakukan sebagai salah satu bahan pertimbangan bagi upaya pengelolaan sumberdaya ikan tongkol secara lestari. Tulisan ini bertujuan untuk mengkaji biologi reproduksi ikan tongkol abu-abu meliputi struktur ukuran, hubungan panjang berat, nisbah kelamin, ukuran pertama kali matang gonad, dugaan musim pemijahan dan kebiasaan makanan.

\section{BAHANDANMETODE Waktu dan Lokasi Penelitian}

Sampel ikan dan pengumpulan data lainnya dilakukan di Pelabuhan Perikanan Nusantara (PPN) Pemangkat, Kalimantan Barat selama periode Februari sampai November 2014.

\section{Pengumpulan Data}

Sampel ikan tongkol abu-abu (Thunnus tonggol) diperoleh secara acak dari hasil tangkapan kapal jaring insang hanyut (lebar mata jaring 3-4 inchi) yang mendarat di Pelabuhan Perikanan Nusantara (PPN) Pemangkat. Pengukuran panjang cagak/fork length $(\mathrm{cm})$ dan berat ikan (gram) dilakukan setiap bulan oleh enumerator. Pengamatan ikan sampel dilakukan dengan pembedahan untuk menentukan jenis kelamin dan tingkat kematangan gonad (TKG) ditentukan berdasarkan ciri organ reproduksi, selanjutnya pengamatan kebiasaan makanan dilakukan dengan melihat isi lambung ikan.

\section{Analisis Data}

Penentuan nisbah kelamin dilakukan dengan perbandingan antara jumlah ikan jantan dan betina. Selanjutnya analisis seimbang atau tidaknya dilakukan dengan uji chi-square pada selang kepercayaaan $95 \%$ $\left(a^{\prime}=0,05\right)$ (Steel \& Torie, 1993).

Analisis hubungan panjang dan bobot ikan tongkol digunakan rumus Hile (1936) dalam Effendie (2002) sebagai berikut :

$\mathrm{W}=\mathrm{a} \mathrm{L}^{\mathrm{b}}$

dimana;

$\mathrm{W}=$ berat ikan (gram)

$\mathrm{L}=$ panjang ikan $(\mathrm{cm})$

a dan b konstanta

Untuk mengetahui nilai $\mathrm{b}=3$ atau $\mathrm{b} \neq 3$ dilakukan uji $\mathrm{t}(t$ test) dengan hipotesis :

$\mathrm{H}_{0}: \quad \mathrm{b}=3$, hubungan panjang bobot bersifat isometric

$\mathrm{H}_{1}$ : $\quad b \neq 3$, hubungan panjang bobot bersifat allometrik dimana: Bila $\mathrm{b}>3$ pola hubungan panjang bobot bersifat allometrik positif (pertambahan berat 
lebih cepat daripada pertambahan panjang) dan bila $\mathrm{b}<3$ allometrik negatif (pertambahan panjang lebih cepat daripada pertambahan berat).

Penentuan tingkat kematangan gonad dilakukan atas acuan Holden \& Raitt (1974) yang terdiri atas lima tingkatan (Lampiran 1.)

Ukuran ikan pertama kali tertangkap atau Length at first capture (Lc) merupakan $50 \%$ fraksi tertahan (ikan yang tertangkap) dari alat tangkap. Nilai Lc diperoleh dari data sebaran panjang yang dihitung dengan rumus (Sparre \& Venema 1999):

SLest $=1 /\left(1+\exp \left(\mathrm{S}_{1}-\mathrm{S}_{2} * \mathrm{~L}\right)\right)$

$\mathrm{Lc}=\mathrm{S}_{1} / \mathrm{S}_{2}$

dimana;

SLest = kurva logistik

$\mathrm{S}_{1}$ dan $\mathrm{S}_{2}=$ konstanta

Pendugaan panjang rata-rata saat pertama kali matang gonad (length at first maturity), dilakukan sesuai metode Spearman-Karber dengan persamaan sebagai berikut (Udupa 1986):

$\mathrm{m}=\mathrm{Xk}+1 / 2-\left(\mathrm{X} x \sum \mathrm{pi}\right)$

dimana;

$\mathrm{m}=$ logaritma panjang ikan pada kematangan gonad pertama

$\mathrm{Xk}=$ logaritma nilai tengah kelas panjang dimana ikan $100 \%$ sudah matang gonad.

$\mathrm{x}=$ rata-rata selisih logaritma nilai kelas panjang

pi $=$ proporsi ikan matang gonad pada kelas ke-i dimana $\mathrm{pi}=\mathrm{ri} / \mathrm{ni}$

Rata-rata ukuran ikan pertama kali matang gonad diperoleh dari nilai antilog $\mathrm{m}$

Indeks Kematangan Gonad (IKG) atau Gonado Somatic Index (GSI) adalah nilai persentase perbandingan berat gonad dan berat ikan, nilai indeks ini semakin lama semakin besar sampai batas kisaran maksimum, kemudian akan terjadi penurunan. Dengan mengetahui IKG ini kita bisa memperkirakan musim memijah ikan. Indeks IKG atau GSI menurut dianalisis dengan rumus Effendie (2002):

$\mathrm{IKG}=(\mathrm{Bg} / \mathrm{Bt}) \times 100 \%$ dimana;

$\mathrm{IKG}=$ indeks Kematangan Gonad

$\mathrm{Bg}=$ berat gonad (gram)

$\mathrm{Bt}=$ berat tubuh ikan - berat gonad $($ gram $)$

Dalam menganalisis kebiasaan makanan, dilakukan dengan indeks bagian terbesar (Index of Preponderance) dalam Effendie (2002) dengan rumus:

$\mathrm{IP}=\left[(\mathrm{Vi} * \mathrm{Oi}) /{ }^{\prime}(\mathrm{Vi} * \mathrm{Oi})\right]^{* 100 \%}$

dimana;

$\mathrm{IP}=$ Index of Preponderance

$\mathrm{V}=$ persentase volume makanan ikan jenis ke- $\mathrm{i}$

$\mathrm{Oi}=$ persentase frekuensi kejadian makanan jenis ke-i

Jika suatu jenis makanan mempunyai nilai IP > 40\% menunjukkan jenis makanan itu termasuk makanan utama, nilai IP 4-40\% berarti jenis makanan itu termasuk makanan pelengkap, dan jika nilai IP < 4\% maka jenis makanan tersebut merupakan makanan tambahan (Nikolsky 1963). Identifikasi ikan yang menjadi mangsa mengacu pada Carpenter \& Niem (2001).

\section{HASIL DAN BAHASAN \\ Hasil}

\section{Struktur Ukuran}

Ukuran tongkol abu-abu hasil tangkapan jaring insang hanyut di Laut Cina Selatan selama Januari sampai November 2014 berkisar antara 35-83 cmFL. Ukuran panjang paling banyak (modus) yaitu $47-49 \mathrm{cmFL}$, dengan rata-rata $46,7 \mathrm{cmFL}$.

\section{Hubungan Panjang-Berat}

Hasil analisis hubungan panjang berat 1840 ekor ikan tongkol abu-abu dihasilkan persamaan $\mathrm{W}=0,0162 \mathrm{~L}^{3,004}$ $\left(r^{2}=0,9671\right)$ dengan nilai $b$ adalah 3,004 (Gambar 2). Berdasarkan hasil uji t pada selang kepercayaan 95\%, nilai b sama dengan 3 atau pola pertumbuhan bersifat isometrik. Artinya pertambahan berat sama dengan pertambahan panjangnya.

\section{Nisbah Kelamin (Sex ratio)}

Nisbah Kelamin tongkol abu-abu dari Laut Cina Selatan secara umum ikan jantan berbanding betina adalah 1,3:1. Nisbah kelamin pada bulan Januari, Maret, April, Mei, Juli, Agustus, September berturut-turut adalah 1,5:1, 0,9:1, 1,3:1, 1,5:1, 1,3:1, 2,4:1, 1:1. (Gambar 3). 


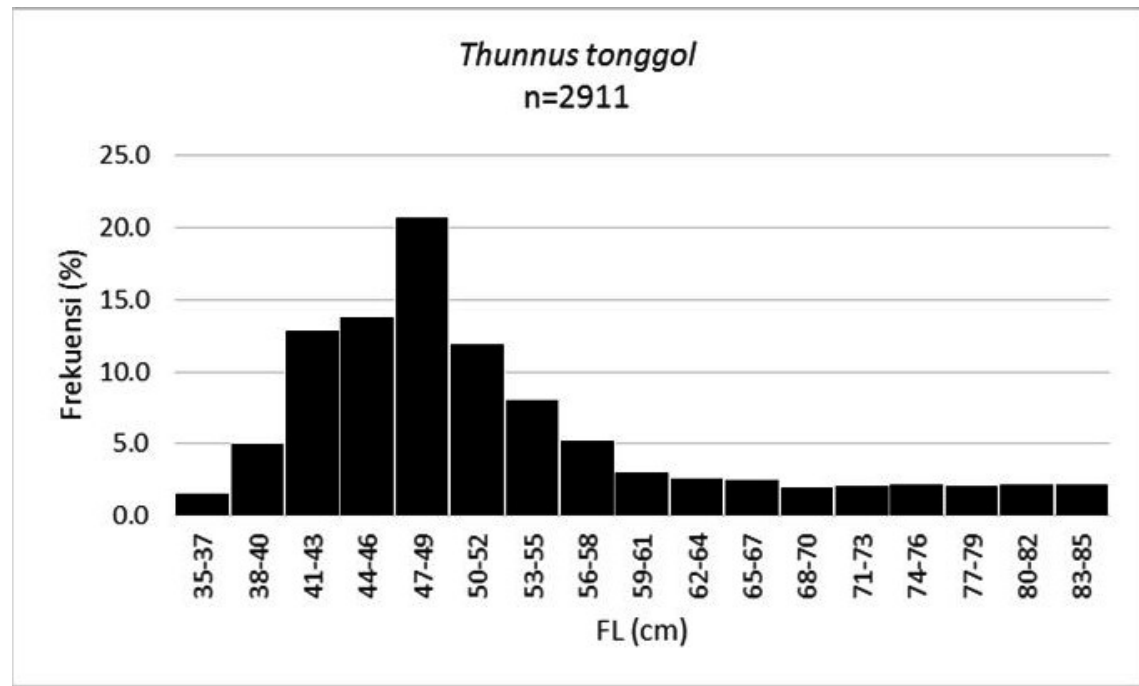

Gambar 1. Sebaran frekuensi panjang tongkol abu-abu.

Figure 1. Length frequency distribution of longtail tuna.

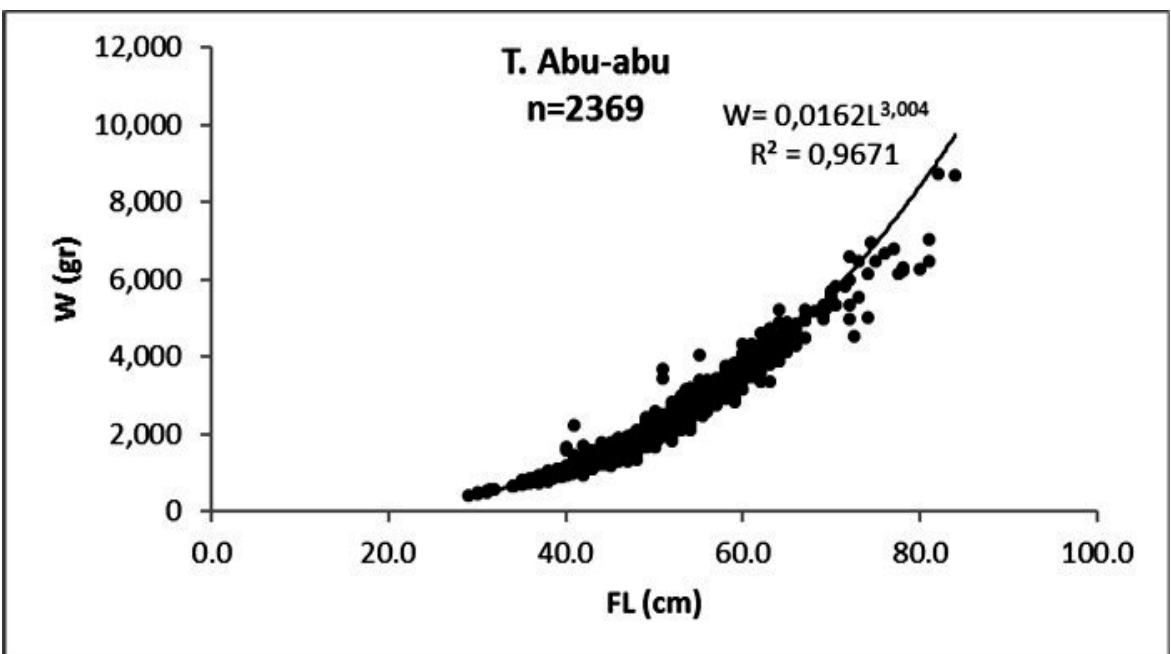

Gambar2. Hubungan panjang berat tongkol abu-abu.

Figure 2. Length weigth relationship of longtail tuna.

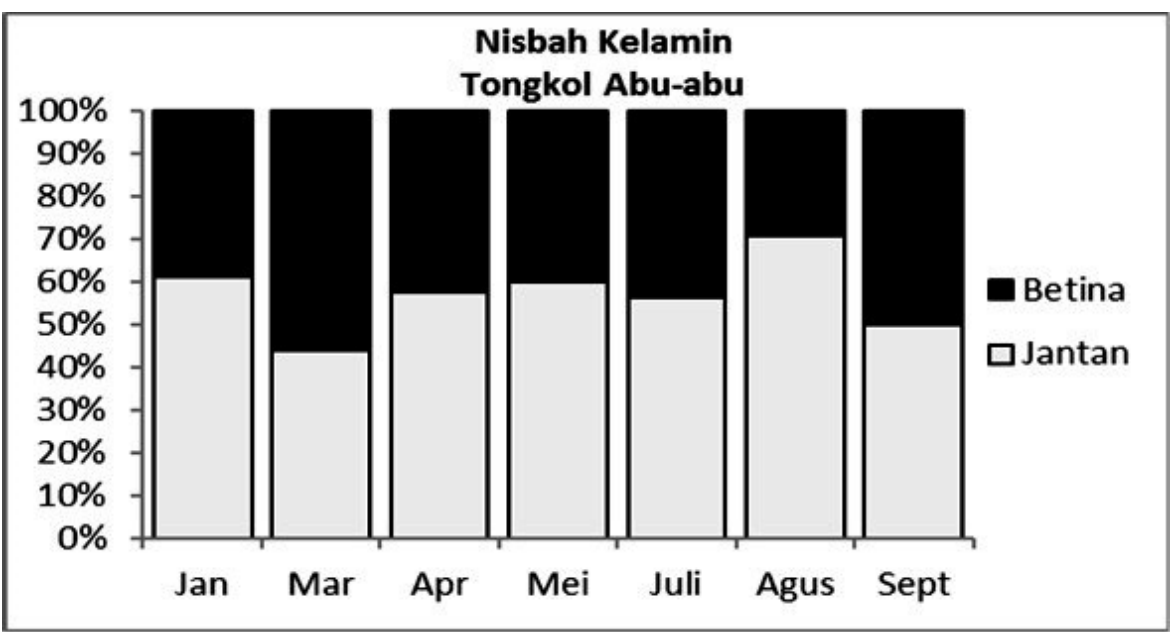

Gambar 3. Nisbah Kelamin tongkol abu-abu dari Januari-September.

Figure 3. Sex ratio of longtail tuna. 
Hasil uji $\mathrm{X}^{2}$ (Chi-square) nisbah kelamin ikan tongkol abu-abu pada selang kepercayaan 95\%, menunjukkan tidak terdapat perbedaan nyata antara jumlah ikan jantan dan betina atau dalam keadaan seimbang.

\section{Pendugaan Ukuran Pertama Kali Matang Gonad (Lm)}

Hasil analisis dengan metode Spearman-Karber menunjukkan ukuran pertama kali matang gonad (Lm) ikan tongkol abu-abu yang tertangkap di Laut Cina Selatan adalah 41,1 cm FL (pada kisaran FL 39,6 - 42,6 cm).

\section{Pendugaan Ukuran Pertama Kali Tertangkap (Lc)}

Hasil analisis menunjukkan ukuran pertama kali tertangkap (Lc) ikan tongkol abu-abu yang tertangkap jaring insang hanyut di Laut Cina Selatan adalah 47,8 cm. (Gambar 4).

\section{Tingkat Kematangan Gonad (TKG)}

Perkembangan TKG tongkol abu-abu pada periode penelitian ini disajikan pada Gambar 5 dan Gambar 6.

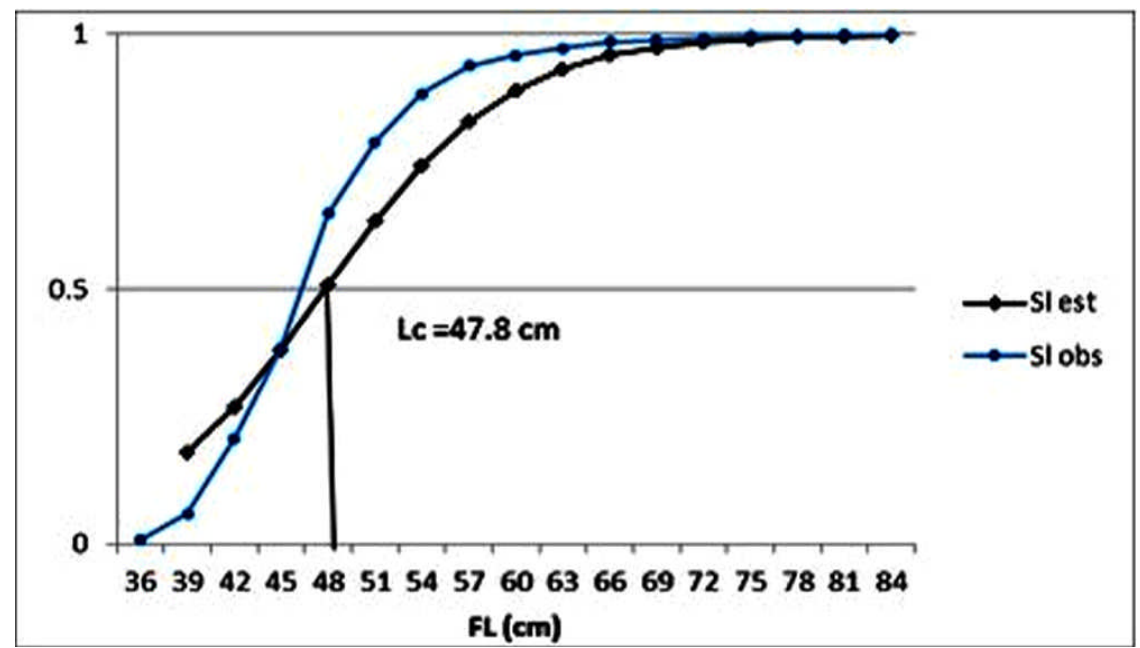

Gambar4. Panjang pertama kali tertangkap (Lc) tongkol abu-abu yang tertangkap jaring insang hanyut di Laut Cina Selatan.

Figure 4. Length at first capture (Lc) longtail tuna caught by drift gill net in the South China sea.

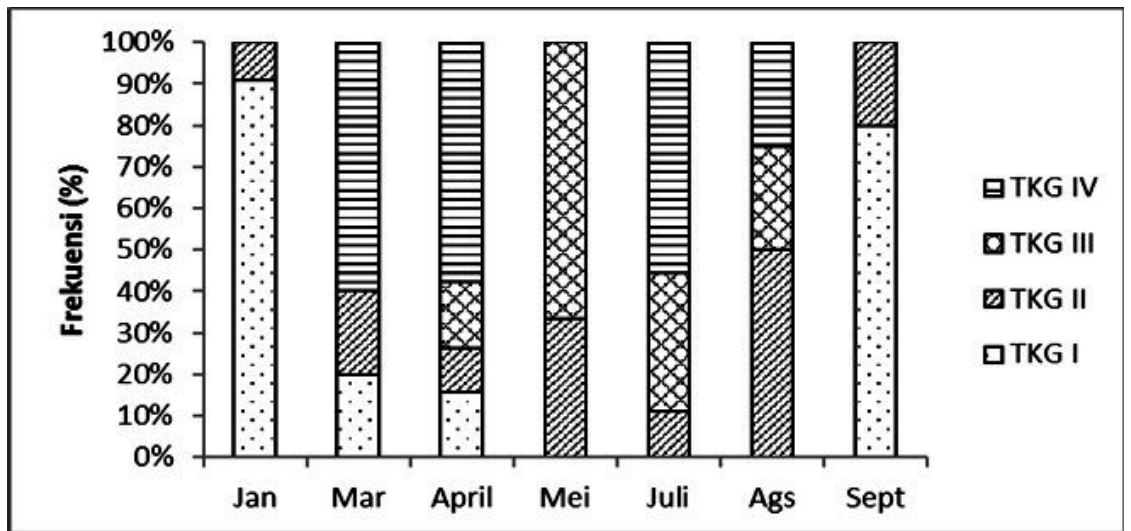

Gambar 5. TKG tongkol abu-abu jantan, Januari-September 2014.

Figure 5. Gonad maturity stage of male longtail tuna, January-September 2014. 


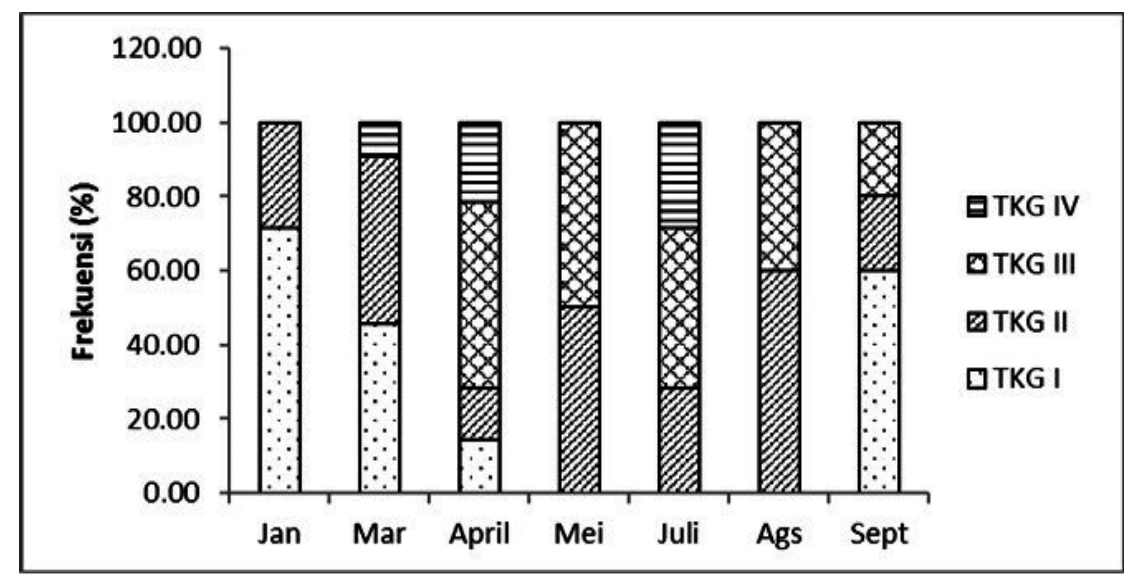

Gambar 6. TKG tongkol abu-abu betina, Januari-September 2014.

Figure 6. Gonad maturity stage of female longtail tuna, January-September 2014.

Dari 140 ekor ikan sampel selama penelitian, yang terdiri dari 80 ekor ikan jantan dan 60 ekor ikan betina, diperoleh perkembangan tingkat kematangan gonad (TKG) dari bulan Januari sampai September dari masing-masing tingkatan berfluktatif. TKG I sampai IV tersebar hampir setiap bulan. Perkembangan TKG ikan tongkol abu-abu betina memperlihatkan bahwa TKG IV paling tinggi pada bulan Juli dan bulan Agustus terjadi penurunan, pada ikan jantan memperlihatkan hal yang hampir sama dimana TKG IV (Gambar 2 dan 3). Dari kondisi tersebut, musim pemijahan ikan tongkol komo di Laut Cina Selatan, Laut natuna dan sekitarnya diduga terjadi pada bulan Agustus.

\section{Indeks Kematangan Gonad (Gonado Somatic Index $=G S I)$}

Indeks kematangan gonad (GSI) tertinggi tongkol abuabu di Laut Cina Selatan pada bulan April dan Juli dan terjadi penurunan pada bulan Mei dan Agustus (Gambar 7).

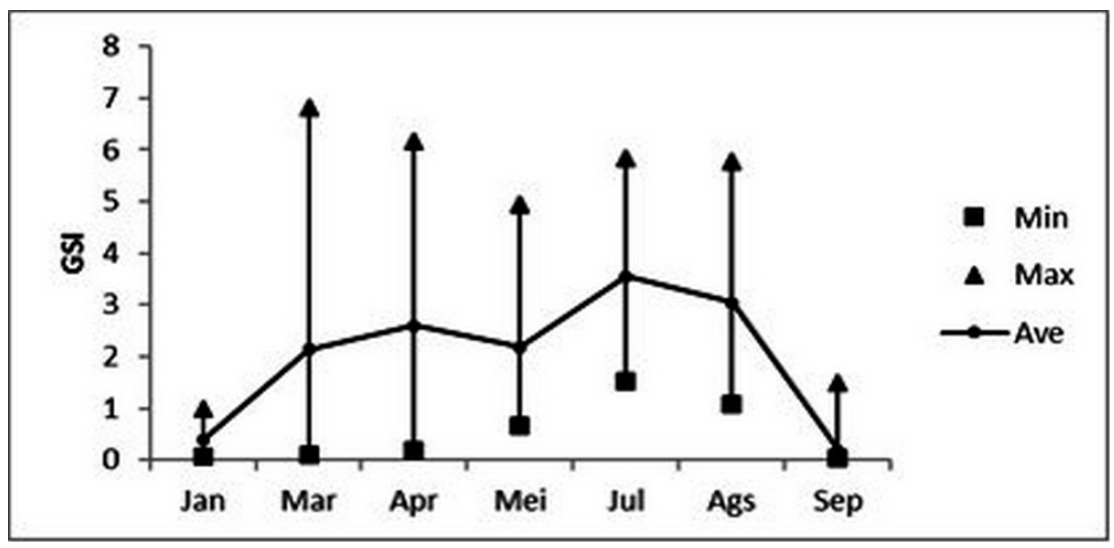

Gambar 7. Indeks Kematangan Gonad tongkol abu-abu di Laut Cina Selatan.

Figure 7. Gonado Somatic Index of longtail tuna in the South China Sea.

\section{Kebiasaan Makanan (Food Habits)}

Hasil analisis isi lambung terhadap 140 ikan sampel, 56 ekor ikan dalam kondisi lambung kosong, 84 ekor ikan tongkol abu-abu dilakukan analisis menggunakan index of preponderans (IP) dapat dilihat pada Gambar 6. Pengamatan pada pada bulan Januari makanan utamanya adalah ikan tembang yang mencapai $92 \%$ dan hancuran ikan sebagai makanan tambahan yang mencapai $7 \%$.
Pada bulan Maret makanan utamanya adalah cumicumi sebesar $89 \%$ dan makanan tambahan berupa hancuran ikan 10\%. Bulan April makanan utamanya adalah cumicumi sebesar $92 \%$ dan makanan tambahan berupa layang dan teri hancuran ikan 10\%. Bulan Juli makanan utamanya adalah cumi-cumi sebesar $75 \%$ dan makanan pelengkap hancuran ikan $25 \%$ dan makanan tambahan berupa ikan petek $0,4 \%$. Bulan Agustus makanan utamanya adalah ikan layang $54 \%$ dan makanan pelengkap berupa cumi-cumi $36 \%$ dan makanan tambahan berupa teri $7,8 \%$ dan hancuran ikan $1 \%$. 


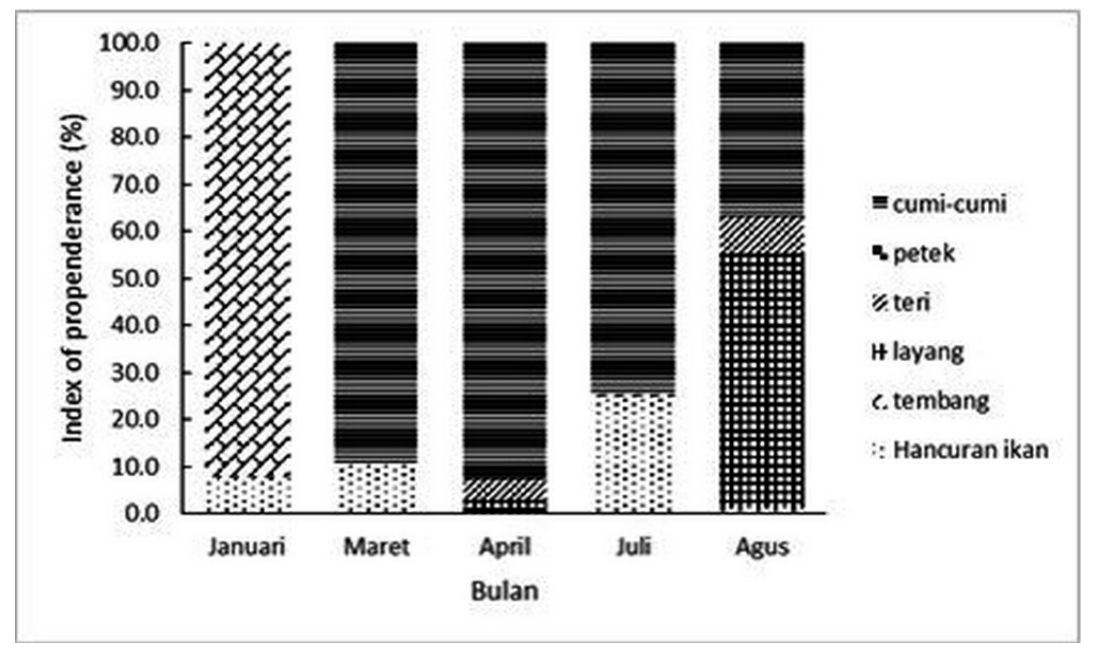

Gambar 8. Komposisi makanan ikan tongkol abu-abu.

Figure 8. The composition of stomach content of longtail tuna.

\section{Bahasan}

Ukuran tongkol abu-abu hasil tangkapan jaring insang hanyut di Laut Cina Selatan selama periode penelitian berkisar antara $35-83 \mathrm{~cm}$, dengan ukuran rata-rata $46.7 \mathrm{~cm}$. Ukuran ikan tongkol abu-abu di Laut Jawa yang berkisar antara 24-60 cm, dengan panjang rata-rata 40,1 cm (Hidayat \& Nugroho, 2013). Abdul Samad et al. (2012), menyatakan ukuran ikan tongkol abu-abu di perairan India berkisar antara: 23-111 cm. sedangkan menurut Yasemi et al., (2017) ukuran ikan tongkol abu-abu di utara Teluk Persia dan perairan Oman 27-107 cm. Sementara Kaymaram et al., (2013) menyatakan ukuran ikan diperairan Teluk Persia dan perairan Oman berkisar 26-125 cm. Sedangkan ukuran ikan diperairan Australia berkisar 30-150 cm (Griffiths et al., 2010). Struktur ukuran ikan tongkol abu-abu yang tertangkap di Laut Jawa dan Laut Cina Selatan lebih kecil terutama ukuran maksimal dibandingkan dengan ukuran di peraian India, Teluk Persia dan Australia, hal ini karena perbedaan kondisi habitat perairan. Selanjutnya Yesaki (1991) menyatakan, hasil studi morfometrik ikan tongkol abu-abu memperlihatkan ada perbedaan subpopulasi di sepanjang rentang distribusinya.

Hasil uji t terhadap nilai $b$, menujukkan pola pertumbuhan ikan tongkol abu-abu bersifat isometrik artinya pertambahan berat sebanding dengan pertumbuhan panjangnya. Hasil penelitian dibeberapa area memperlihatkan nilai b yang berbeda (Tabel 1). Perbedaan sifat pertumbuhan ikan ini dipengaruhi oleh keturunan, penyakit, ketersediaan makanan dan habitat (Effendi, 2002).

Tabel 1. Hubungan panjang berat tongkol abu-abu dari beberapa lokasi

Table 1. Length-weght relationship of longtail tuna from different area

\begin{tabular}{llll}
\hline Penulis /author & Lokasi/area & a & b \\
\hline James et al. (1993) & India & 0,00008 & 2,71 \\
Khorshidian \& Carrara (1993) & Iran & 0,0015 & 2,43 \\
Darvishi et al. (2003) & Iran & 0,00004 & 2,7 \\
Kaymaram et al. $(2013)$ & Iran & 0,00002 & 2,83 \\
Griffiths et al. (2010) & Australia & 0,00005 & 2,82 \\
Abdussamad et al. (2012) & India & 0,0148 & 3,00 \\
Penelitian ini & Laut Cina Selatan & 0,0162 & 3,00 \\
\hline
\end{tabular}

Hasil uji chi-square nisbah kelamin secara umum tongkol abu-abu antara jantan dan betina di Laut Cina Selatan adalah tidak berbeda nyata atau dalam kondisi seimbang, kecuali pada bulan Agustus. Dibandingkan dengan hasil penelitian lainnya nisbah kelamin ikan ini menunjukkan hasil yang sama yaitu tidak ada perbedaan yang signifikan antara jumlah ikan jantan dan betina atau dalam kondisi seimbang. (Klinmuang, 1978; Wilson, 1981;
Yesaki, 1982; Griffiths et al., 2010; Hassadee et al., 2014). Jika nisbah kelamin dalam kondisi seimbang maka kemungkinan terjadi pembuahan sel telur oleh spermatozoa semakin besar (Effendi, 2002). Nisbah kelamin yang berada pada kondisi seimbang diperlukan untuk mempertahankan kelangsungan hidup suatu populasi atau setidaknya ikan betina lebih banyak dari jantan (Bal \& Rao, 1984). Nisbah kelamin bulan Agustus jantan:betina 
menunjukkan jantan lebih banyak dibanding betina, hal ini bertepatan dengan musim pemijahan. Beberapa hasil penelitian memperlihatkan bahwa sex ratio pada saat pemijahan tidak seimbang. Chiou \& Chen (1993) menyatakan bila nisbah kelamin jantan lebih besar daripada betina pada saat memijah menunjukkan bahwa spesies ini memiliki fekunditas tinggi. Sedangkan bila nisbah kelamin betina lebih tinggi daripada jantan pada saat memijah menunjukkan spesies ini memiliki fekunditas rendah $(\mathrm{Wu}$ etal., 2008).

Ukuran pertama kali matang gonad (Lm) ikan tongkol abu-abu yang tertangkap di Laut Cina Selatan adalah 41,1 cm FL (pada kisaran FL 39,6 - 42,6 cm). Ukuran pertama kali matang gonad (Lm) ikan ini di perairan Thailand adalah 39,6 cm (Chuenpan,1985). Menurut Wilson (1981) di perairan Papua Nugini ikan ini pertama kali memijah pada ukuran $61 \mathrm{~cm}$. Sementara Yesaki (1982), menyatakan nilai Lm ikan ini di perairan Thailand adalah $43 \mathrm{~cm}$ FL. Sedangkan menurut Abdussamasd et al. (2012) Ukuran pertama kali matang gonad ikan jantan dan betina adalah 40,77 and 42,16 cmFL.

Ukuran pertama kali tertangkap (Lc) ikan tongkol abuabu yang tertangkap jaring insang hanyut di Laut Cina Selatan adalah $47,8 \mathrm{~cm}$. Nilai Lc ini lebih besar dari nilai Lm yaitu $41,1 \mathrm{~cm}$, dari hasil ini diketahui bahwa sebagian besar ikan tongkol abu-abu yang tertangkap sudah melewati ukuran pertama kali matang gonad ( $\mathrm{Lc}>\mathrm{Lm}$ ). Hal ini menunjukkan bahwa alat tangkap jaring insang hanyut ramah lingkungan terhadap ikan tongkol abu-abu karena menangkap ikan-ikan yang sudah dewasa sehingga bisa terjadi rekrutmen. Jaring insang hanyut ini bisa dipertahankan keberadaannya bahkan apabila ada penambahan upaya/unit penangkapan sebaiknya jenis alat tangkap ini direkomendasikan.

Indeks kematangan gonad (GSI) tertinggi tongkol abuabu di Laut Cina Selatan pada bulan April dan Juli dan terjadi penurunan pada bulan Mei dan Agustus (Gambar 7). Sehingga musim pemijahan tongkol abu-abu terjadi pada bulan Mei dan Agustus. Hal ini sesuai dengan Widodo (1988) dan Claereboudt et al. (2005) yang menyatakan ikan memijah biasanya sebulan kemudian setelah puncak IKG (indeks kematangan gonad).

Berdasarkan analisis GSI dan TKG musim pemijahan tongkol abu-abu terjadi pada bulan Mei dan Agustus. Hal ini sama dengan musim pemijahan tongkol abu-abu di perairan Thailand terjadi pada bulan Mei dan Agustus (Hassadee et al., 2014). Musim memijah ikan ini di perairan India yang terjadi pada bulan Oktober-November (Abdussamasd et al., 2012). Sedangkan musim memijah ikan ini di perairan Taiwan sekitar bulan Desember (Wei et al., 2011). Sementara Cheunpan (1984) menyatakan musim memijah ikan ini di perairan Thailand adalah bulan MaretMei dan Juli-Desember. Perbedaan musim memijah dikarenakan kondisi perairan/habitat ikan ini berbedabeda.

Kebiasaan makanan ikan tongkol abu-abu menunjukkan makanan utamanya ikan tembang, cumi-cumi dan ikan layang. Makanan pelengkap berupa cumi-cumi dan hancuran ikan. Sedangkan makanan tambahan ikan teri, ikan petek dan hancuran ikan. Hasil penelitian ini menunjukkan bahwa ikan tongkol abu-abu tergolong ikan karnivora yang preferensi makanannya tidak sama tiap bulan artinya bersifat opportunistik, memakan mangsa yang banyak tersedia saat itu di alam. Hal ini hampir sama dengan Collete \& Nauen (1983) yang menyatakan bahwa ikan ini tergolong karnivora yang makanannya terdiri dari berbagai jenis krustacea, chephalopoda dan ikan. Griffiths et al. (2007) menyatakan ikan ini merupakan predator opportunistik yang memangsa ikan pelagis kecil, chephalopoda dan krustacea dan juga terindikasi ada perbedaan komposisi makanan sesuai dengan waktu, tempat dan ukuran ikan.

Informasi hasil penelitian dapat dijadikan referensi untuk mengambil kebijakan misalnya untuk penutupan musim penangkapan (close seasion) yang berdasarkan musim pemijahan. Informasi mengenai ukuran matang gonad bisa dijadikan dasar untuk pengelolaan misalnya ukuran legal (legal size), selain dibuat aturan legal size maka alat tangkap yang digunakan misalnya terhadap besarnya mata jarring (mesh size) yang diperbolehkan seperti dilakukan di Australia (Griffiths, 2010). Berdasarkan kebiasaan makanannya dan ukuran matang gonad pada masa yang akan datang untuk ikan tongkol abu-abu bisa dikembangkan metode penangkapan lain misalnya dengan wisata pancing (recreational fishing) seperti di Australia (Griffiths et al., 2010). Wisata pancing bisa diatur dengan penggunaan ukuran mata pancing agar ikan tongkol abuabu yang tertangkap adalah yang sudah dewasa.

\section{KESIMPULAN}

Dari hasil penelitian menunjukkan tingkat pemanfaatan ikan tongkol abu-abu masih bisa dikembangkan dengan mempertimbangkan kuota ukuran yang boleh ditangkap, waktu dan daerah penangkapan serta alternatif alat tangkap yang ramah lingkungan. Untuk kebijakan pengelolaan yang lestari dapat direkomendasikan penetapan penutupan daerah penangkapan pada bulan Mei dan Agustus pada wilayah perairan yang diduga sebagai daerah pemijahan, penetapan kuota ukuran tangkapan lebih besar dari nilai $\mathrm{Lm} 41,1 \mathrm{~cm}$ dan alternatif wisata pancing dengan ukuran mata pancing yang hanya menangkap ukuran yang sudah dewasa. 


\section{PERSANTUNAN}

Makalah ini merupakan kontribusi dari Kegiatan Penelitian Aspek Biologi, Tingkat Pemanfaatan dan Optimasi Pemanfaatan Sumberdaya Ikan Pelagis Besar Di WPP 571 Selat Malaka Dan WPP 711 Laut Cina Selatan Untuk Mendukung Industrialisasi Perikanan, Balai Penelitian Perikanan Laut Tahun Anggaran 2014.

\section{DAFTAR PUSTAKA}

Abdussamad, E. M., Said Koya, K. P., Ghosh, S., Rohit, P., Joshi, K. K., Manojkumar, B., Prakasan, D., Kemparaju, S., Elayath, M. N. K., Dhokia, H. K., Sebastine, M., \& Bineesh, K. K. (2012). Fishery, biology and population characteristics of longtail tuna, Thunnus tonggol (Bleeker, 1851) caught along the Indian coast. Indian. J. Fish. 59(2), 7-16.

Bal, D.V. \& Rao, K.V. (1984). Marine fisheries (p. 5-24). Tata Mc Graw-Hill Publishing Company Limited, New Delhi.

Carpenter, K. E, \& Niem, V. H. (2001). The living marine resources of the Western Central Pacific. Volume 6. Bony Fishes Part 4 (Labridae to Latimeriidae), Estuarine Crocodiles, sea turtles, sea snakes, and marine mammals (p. 3511-4232). FAO Species Identifikastion Guide For Fisheries Purposes. FAO of the United Nations, Rome.

Cheunpan, A. (1984). Sexual maturity, size at maturity and spawning season of longtail tuna (T. tonggol), eastern little tuna (E. affinis) and frigate mackerel (A. thazard) in the Gulf of Thailand. Fisheries Report of the Marine Fisheries Division of the Department of Fisheries, Bangkok. 43, 33.

Chiou, W. D. \& Chen, C.T. (1993). Age and growth of the white-tongued crevalle, Uraspis helvolus, in Suao coastal water of northeastern Taiwan. J. Fish. Soc. Taiwan. 20, 125-134.

Collete, B.B. \& Nauen, C.E. (1983). FAO special catalogue. Vol. 2 Scombrids of the world an annotated and illustrated catalogue of tunas, mackerels, bonitos, and related species known to date. FAO Fisheries Synopsis.125 (2), 92-93.

Claereboudt, M. R., Mc Ilwain, J. L., Al-Oufi, H. S., \& AmbuAli, A.A. (2005). Patterns of reproduction and spawning of the king fish (Scomberomorus commerson, Lac'ep'ede) in the coastal waters of the Sultanate of Oman. Fish. Res. 73 (3), 273-282.
Effendie, M. I. (2002). Biologi Perikanan (p.163). Yayasan Pustaka Nusantara. Bogor.

Froese, R. \& Pauly, D.E. (2009). FishBase, version 02/2009. www.fishbase.org. diakses tanggal 11-1-2015.

Griffiths, S.P., Pepperell, J.G., Tonks, M.L., Sawynok, W., Olyott, L., Tickell, S., Zischke, M.T., Burgess, J., Jones, E., Joyner, D., Lynne, J., Makepeace, C., \& Moyle, K. (2010). Biology, fisheries and status of longtail tuna (Thunnus tonggol), with special reference to recreational fisheries in Australian waters. FRDC Final Report 2008/058.p. 101.

Griffiths, S.P. (2010). Stock assessment and efficacy of size limits on longtail tuna (Thunnus tonggol) caught in Australian waters. Fish. Res. 102, 248-257.

Griffiths, S.P., Fry, G.C., Manson, F.J. \& Pillans, R.D. (2007). Feeding dynamics, consumption rates and daily ration of longtail tuna (Thunnus tonggol) in Australian waters, with emphasis on the consumption of commercially important prawns. Mar. And Freshwat. Res. 58, 376-397.

Hassadee, P., Yakoh, A., Nootmorn, P., Puntuleng, P., Songkaew, N. \& Kruanium, U. (2014). Reproductive biology of longtail tuna in Thai Waters. IOTC-2014WPNT04-27. p. 1-9.

Hidayat, T. \& Noegroho, T. (2013). Perikanan jaring insang hanyut di Laut Jawa. Bunga Rampai. Status Pemanfaatan Sumberdaya Ikan di Perairan Laut Jawa. Balai Penelitian Peikanan Laut. 235-243.

Holden, M.J. \& Raitt, D.F.S. (1974). Manual of fisheries science. FAO Fish. Tech. Pap. 115, 1-214.

Kaymaram, F., Darvishi, M., Behzadi, S. \& Ghasemi, S. (2013). Population dynamic parameters of Thunnus tonggol in the north of the Persian Gulf and Oman Sea. Iranian Jour. of Fish. Sci. 12(4), 855-863.

Klinmuang, H. (1978). Preliminary studies on the biology of tunas in the west of the Gulf of Thailand and off the east coast of Peninsular Malaysia. Fisheries Report of the Marine Fisheries Division of the Department of Fisheries, Bangkok. 5, 27.

Nikolsky, G. V. (1963). The ecology of fishes (p.352). Academic Press. London.

Sparre, P, \& S.C Venema. (1999). Introduksi Pengkajian Stok Ikan Tropis (p. 238). Buku I. Manual. Terjemahan. FAO-DANIDA-Puslitbang Perikanan DEPTAN-RI. 
Steel, R.G.D, \& Torrie, H. (1993). Prinsip dan prosedur statistika suatu pendekatan biometric (p. 333). Diterjemahkan oleh Bambang Sumantri. PT Gramedia Pustaka Utama. Jakarta.

Udupa, K.S. (1986). Statistical method of estimating the size at first maturity in fishes. ICLARM, Metro Manila, Fishbyte. 4 (2), 8-10.

Wei, C.C., Hong, H.H., Shin, C.F., Shin, C.C., Chi, L.S., Wen, Y.C., Don, C.L., \& Wei, C.S. (2011). Reproductive biology of longtail tuna (Thunnus tonggol) from coastal waters off Taiwan. IOTC-2011-WPNT01-30. $1-15 \mathrm{p}$.

Wilson, M.A. (1981). The biology, ecology and exploitation of longtail tuna, Thunnus tonggol (Bleeker) in Oceania (p. 195). M.Sc. Thesis. School of Biological Sciences, Macquarie University, Sydney.

Widodo, J. (1988). Population Dynamic and Management of "Ikan Layang”, Scad Mackerel, Decapterus spp (Piscess: Carangidae) in Java Sea (p. 150). Dissertation Doctor of Philosophy. University of Washington.
Wujdi, A, \& Suwarso. (2014). Fluktuasi dan komposisi hasil tangkapan tuna neritik tertangkap jarring insang di perairan Laut Cina selatan. J. Lit Perik. Ind. 20 (4), 207-214.

Wu, C.C., Weng, J.S., Liu, K.M., \& Su, W.C. (2008). Reproductive biology of the notchedfin threadfin bream, Nemipterus peronii (Nemipteridae), in waters of Southwestern Taiwan. Zoological Studies. 47(1), 103-113.

Yesaki, M. (1982). Thailand. Biological and environmental observations. A report prepared for the Pole-and-Line Tuna Fishing in Southern Thailand Project. FAO FI: DP/THA/77/008: Field Doc. 3, 46.

Yesaki, M. (1991). A review of the biology and fisheries for longtail tuna (Thunnus tonggol) in the Indo-Pacific Region. FAO Fisheries Technical Paper. 370-380.

Yasemi, M., Bajgan, A.N., \& Parsa, M. (2017). Determining the growth and mortality parameters of longtail tuna (Thunnus tonggol Bleeker, 1851) using length frequency data in coastal water of nortern Persian Gulf and Oman Sea, Iran. Int. Aquat. Res. DOI 10.1007/ s40071-017-0170-5. 
Lampiran 1. Tingkat kematangan gonad ikan

Appendix 1. Gonad maturity stage of fish

\begin{tabular}{cl}
\hline $\begin{array}{l}\text { Tingkat Kematangan gonad } \\
\text { (Gonad maturity stage) }\end{array}$ & Keterangan/Remarks \\
\hline I & Ovarium dan testes, panjang 1/3 rongga perut Ovarium transparan dan \\
(Belum matang) & kemerah-merahan Telur tidakn dapat dilihat dengan mata biasa \\
II & Panjang ovarium dan testes sekitar $1 / 2$ rongga perut. Ovarium transparan \\
(Belum matang) & dan kemerah-merahan Telur belum bisa dilihat dengan mata biasa. \\
III & Panjang ovarium dan testes sekitar $2 / 3$ rongga perut. Ovariurium \\
(matang) & kuring kemerah-merahan dan butiran telur sudah nampak \\
IV & Panjang ovarium $2 / 3$ dari rongga perut. Ovarium berwarna orange dengan \\
(matang) & pembuluh darah kurang jelas. Butiran telur terlihat jelas \\
V & Ovarium mengerut sampai $1 / 2$ dari rongga perut sebagai tanda sudah \\
(spent) & terjadi pemijahan, tetap masih ada butir-butir telur. \\
\hline
\end{tabular}

Sumber/Source : Holden \& Raitt (1974) 
Lampiran 2. Gambar sebaran frekuensi panjang bulanan tongkol abu-abu Appendix 2. $\quad$ Figure monthly length frequency distribution of longtail tuna

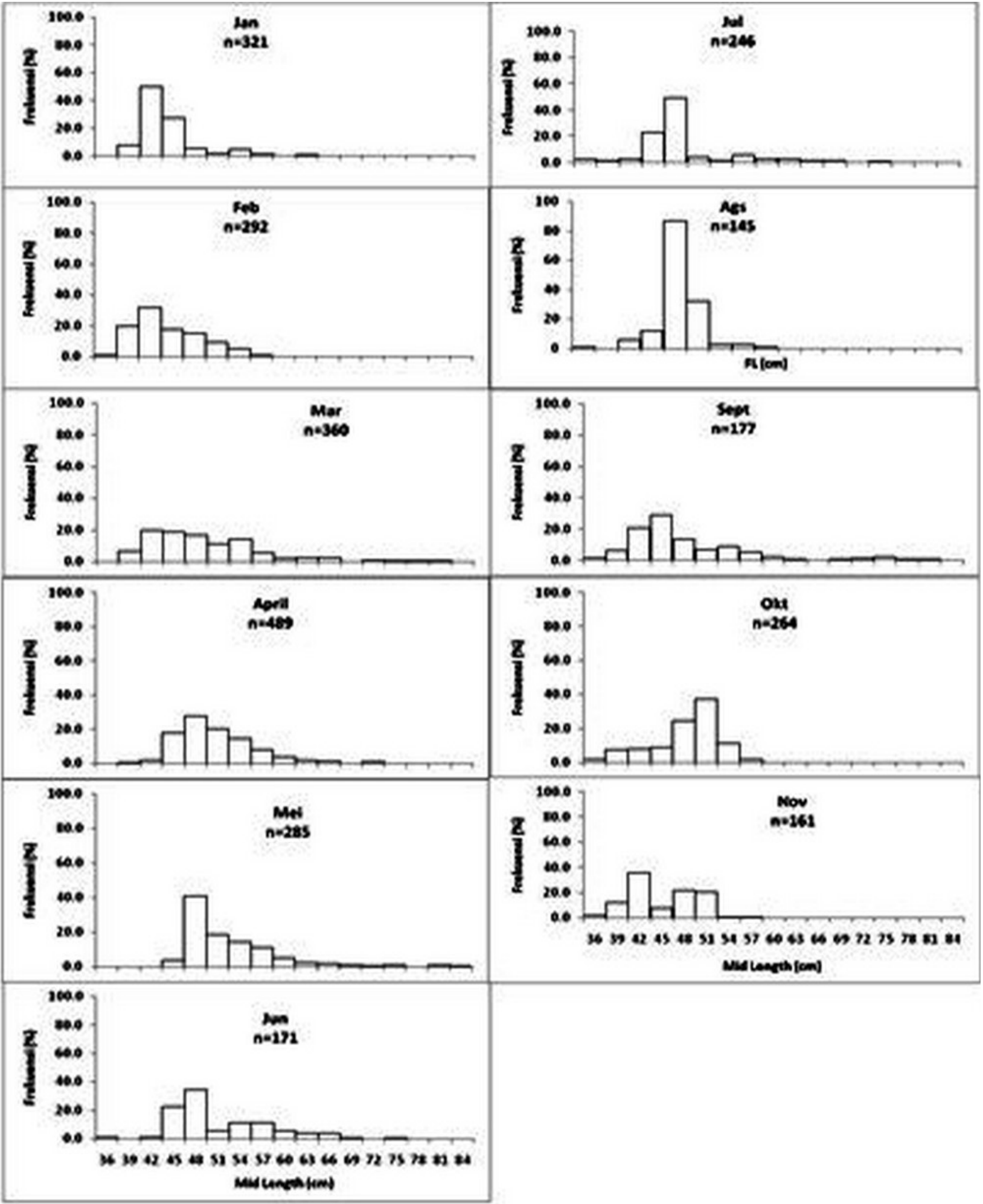

